Session 1793

\title{
Assessing a Big Ten University's Faculty Mentoring Network Program
}

\author{
Mara H. Wasburn, Joseph M. La Lopa \\ Purdue University
}

\begin{abstract}
This study describes a formal mentoring program at Purdue University developed with the explicit goals of helping faculty become better educators, cope with the demands of research and service, and advance toward promotion and tenure. After describing the theoretical model on which the program is based, as well as its structural features, research on its operation is presented. Attention is focused on mentor-protégé communication, strength of mentor-protégé relationships, and on both intended and unintended consequences of the mentoring program. On the basis of interviews with participants, recommendations are offered for improvements that might be incorporated in those programs offered at other institutions that are now experimenting with formal mentoring projects.
\end{abstract}

Introduction

Mentoring has a long, rich tradition dating back to Greek mythology. Mentor (in reality the disguised goddess Athena) was the wise tutor/advisor for Odysseus' son Telemachus in Homer's Odyssey. In this paper, a mentor is defined as anyone who provides guidance, support, knowledge, and opportunities for whatever period the mentor and protégé deem this help to be necessary. ${ }^{1}$ The definition was qualified by Haring, who observed that this help occurs during a period of transition. ${ }^{2}$ This traditional style of mentoring is referred to as "grooming mentoring," and is a dyadic relationship. ${ }^{3}$ By contrast, "networking mentoring" is non-hierarchical in nature, and generally involves more than two participants. This type of mentoring is egalitarian in nature, with mentors and protégé exchanging roles as the situation requires. Implicit in this model is the expectation that each person will contribute something to the network for the mutual benefit of all. ${ }^{3,4}$

The purpose of this paper is to assess a mentoring program for faculty begun at Purdue University in 1997 in which the authors participated. The primary purpose of the program was to foster dialogue about classroom teaching. Interest focuses on the characteristics of those who decided to become involved in the program, the nature and strength of the relationships that developed between mentoring pairs, the extent to which the participants felt that their teaching had improved as a result of their mentoring, and participant recommendations for improving the program. Suggestions derived from the study can be incorporated into existing programs or serve as a foundation for developing new mentoring programs at other colleges and universities. 
The Benefits of Mentoring, with Some Caveats

When asked to reflect on their career successes, many if not most people point to role models who helped and/or influenced them. In academe, mentoring programs for new faculty, both formal and informal, have grown in number in recent years. 5 Many of those embarking on new careers have concerns about their competence, their ability to succeed, and their understanding of and ability to navigate the organizational culture in which they find themselves. ${ }^{6,7}$ They often feel isolated in their new milieu, and uncertain of exactly how to fulfill their job requirements, ${ }^{8,9}$ which can ultimately lead to feelings of alienation. ${ }^{6}$

Research indicates that mentored employees tend to have greater job satisfaction, obtain promotions more quickly, and make higher salaries than those who are not mentored. ${ }^{1,10}$ The mentoring relationship, whether formal or informal, has the potential of facilitating the protégé's successful transition into his/her new role. ${ }^{11}$

Mentors can fulfill both career and psychosocial functions. By virtue of their experience and position within an organization, mentors can enhance the careers of their protégés by sponsoring them, making them visible within the organization, coaching them, protecting them, and ensuring that they are given challenging assignments where they will be noticed. If the relationship between mentor and protégé develops into one of mutual trust, the mentor can provide role modeling, acceptance, validation, counseling, and friendship. ${ }^{5}$

Yet despite these benefits, faculty mentoring relationships do not always produce positive results. Personality differences can doom a mentoring relationship from the outset. Failure to make the goals of the relationship clear can lead to the mentor pushing an agenda with which the protégé does not agree, leaving the protégé to feel that his/her goals have been marginalized. ${ }^{12}$ Failure to allow sufficient time for the relationship to grow and mature can lead to disappointment and frustration. Selby suggests that mentoring programs can be time consuming and have paternalistic overtones, carrying with them the implication that new faculty members are incapable of approaching senior colleagues informally for the help they need, thereby undermining the self-confidence and self-esteem of the protégé. ${ }^{13}$

\section{Formal Mentoring Programs}

It is commonly believed that "true" mentoring is an inherently informal process in which mentors and protégés come together spontaneously. Successful mentoring relationships are seen as a combination of common goals, individual personalities, and a healthy dose of luck. Hence, many organizations have been reluctant to create formal programs. ${ }^{14}$

In the case of colleges and universities, relying upon mentoring to occur on its own has often meant that most new faculty members are never mentored. ${ }^{15}$ Recognizing the need for the benefits of mentoring to reach a greater number of new faculty members, many universities have created such programs. 7, 16 However, The New Faculty Project, which studied new faculty hires for the National Center on Postsecondary Teaching, Learning, and Assessment, discovered that despite the attention paid to mentoring programs, the proportion of new faculty who have mentors has remained unchanged for the past ten years. Of those who do have mentors, most are 
assigned pairings within their departments. Very few mentoring programs exist across departmental lines. ${ }^{17}$

In the most common type of mentoring program, departmental mentors are assigned to incoming faculty to assist them in all phases of their careers: teaching, research, and service. ${ }^{18}$ Cawyer conducted an instrumental case study of a new faculty member in a Department of Communication at an unidentified Research I University. ${ }^{19}$ This methodology uses a particular case to gain insight into an issue or theory, ${ }^{20}$ in this instance the mentoring relationship. The protégé was assigned a mentor by her department chair. The relationship between mentor and protégé was analyzed along five dimensions: interpersonal bonding, social support, professional advice, acculturation to the University, and accessibility. Because her assigned mentor was not accessible, the protégé sought out other colleagues for much of the professional advice and support she needed. The authors concluded that the key variable in the success or failure of the mentoring relationship is the mentor's accessibility.

Boyle \& Boice described a formal mentoring program for new faculty at a large, public comprehensive university. ${ }^{21}$ Twenty-five pairs completed the year-long program. Pairings were made without regard to school or department. The pairs agreed to participate for at least one academic year. Participation was defined as meeting weekly in pairs and monthly as a group. The monthly meetings included some discussion of the mentoring literature and progress reports from the mentoring pairs. They also agreed to participate in the study under discussion. Results of the study revealed a high level of participation. Only 3 pairs missed more than 3 of the weekly meetings, and only 5 of the 50 participants missed more than two monthly meetings. Factors identified for the low rate of absenteeism: telephone calls to the participants, bonding, and the group-meeting format.

A program similar to the Purdue program, discussed below, was created at Montclair State University in 1994-95. ${ }^{7}$ The goals of the New Faculty Mentoring Program are to integrate new faculty members' classroom experiences, a broad university perspective, and the faculty member's overall careers needs. Mentors are selected from the five schools within the University by excellence of teaching, good interpersonal skills, and willingness to give time to their protégés. Individual meetings are combined with weekly, two-hour group sessions. Mentors have multiple protégés, and are expected to form individual relationships with each one, giving both career and psychosocial advice and support. The program is assessed each year and changes made based on the findings. One protégé commented, "She asked what I needed and gave it - sent things to me, remembered me." Another observed, "My mentor invited me to lunch and got in touch with me a lot. He had the patience to be available and answer questions."7

The mentors, too, benefited: "Mentoring others forced me to think about my own career and teaching methods". Another mentor appreciated the "time to step back from your own rat race to try a better way to do things, to clarity my philosophy of teaching." A third member observed, "Being a mentor lit a fire under me and got me excited about my own career and teaching." Benefits of the program are viewed as accruing not only to the participants but also to the University community as a whole. 
Not all the outcomes of the Montclair State program were positive. One mentor's continued absence from group meetings chilled the atmosphere. One protégé's mentor was described as "more interested in blowing his own horn than in any meaningful interaction." Another protégé agreed: "I have a lot of anger about my interaction with my mentor. All he did was offend and talk and never listened to the protégés."7

The Montclair State program described above relies heavily on the group as mentor, a networking mentoring model discussed above. ${ }^{2,3}$ As will be seen below, that approach stands in sharp contrast to the Purdue's Faculty Mentoring Network program's reliance on the dyadic interactions of mentor and protégé(s).

The Faculty Mentoring Network at Purdue University

The Faculty Mentoring Network (FMN) was conceived and implemented by the Teaching Academy at Purdue University. The mission of the Teaching Academy, according to its homepage is to "provide leadership and serve as a catalyst to enhance and strengthen the quality of undergraduate, graduate, and outreach teaching and learning." The Academy delivers on its mission by (a) providing all interested faculty, staff, and students the opportunity to talk, learn, and work together on important and meaningful educational initiatives, and (b) sponsoring programs and activities fostering educational creativity, innovation, and effectiveness both in and outside the classroom. The Academy itself is comprised of Purdue's most outstanding teachers as selected by criteria noted below. They are committed to the continual improvement of teaching and learning at Purdue University. The Teaching Academy is empowered by the Office of the Provost to work with Purdue faculty, the Center for Instructional Excellence (CIE), and interested others to provide quality teaching to students who attend the University.

In late 1997, the Teaching Academy began discussion of a university-wide mentoring program to help faculty hone their teaching skills. A sub-committee collected information on various faculty mentoring programs at Purdue and also turned to other universities such as Penn State, Stanford, and University of Wisconsin to examine the structure and organization of their mentoring. The sub-committee also reviewed a "networking model of mentoring" that was created at Purdue in 1997, and surveyed the literature on mentoring. ${ }^{22}$

One of the key pieces of research indicated that mentoring has both psychosocial and vocational functions. ${ }^{23}$ The psychosocial functions of mentoring consist of (a) role modeling (the mentor can be observed while functioning in various roles or situations), (b) encouragement (the mentor works to raise the confidence of the protégé, (c) counseling (the mentor dissuades the fears of the protégé or discusses the protégés professional and personal matters, and (d) colleagueship (the protégé perceives him/her self to be the mentor's peer).

The vocational functions on the other hand involve the mentor in actively "educating" the protégé to advance his/her skills through critical feedback. It may take the form of "consulting" with the protégé about the political landscape that exists at the workplace or community and then "coaching" him/her to create and implement a plan of action that will lead to the success of the protégé. The vocational functions also include "sponsoring" protégés by speaking favorably of them before key individuals in the workplace or nominating them for key positions. This, in turn 
promotes the "visibility and exposure" the protégé needs to be considered for opportunities that would advance his/her career in the future. Finally, the mentor may need to "protect" the protégé by blunting negative publicity or taking the blame for mistakes made by the protégé.

In 1998, the FMN subcommittee established five goals for the program: (a) help interested faculty become better educators, (b) help faculty cope with demands of research and service, (c) help faculty work toward promotion, (d) be an advocate for faculty members, and (e) provide mentors the opportunity to observe junior faculty members' teaching. The subcommittee spent the remainder of the year discussing a program that would compliment the existing departmental and school-based mentoring programs at Purdue.

In spring of 1999, the FMN program began to take shape. According to the information presented in its draft brochure, the Teaching Academy planned to organize the FMN as a way to provide resources for junior faculty who wanted to improve their teaching skills. The FMN was not to compete with existing department or school mentoring programs, but rather to supplement them. The goal was also to have protégés obtain mentors from outside their departments so that they could develop under the tutelage of faculty who would not be on their promotion and tenure committee, thus restricting the likelihood that politics would enter into the relationship. This also would provide a richness of diversity to the relationship. The draft brochure also stated that the "FMN was designed to: (a) bring together outstanding teacher-scholars from across the curriculum, (b) cultivate dialogue on teaching among faculty, staff, and students, and (c) foster educational creativity, innovation, and effectiveness both in and outside of the classroom."

The first class of mentors was solicited from Purdue's Teaching Academy Fellows. These are faculty members who were recipients of the University's highest teaching award, were nominated by their deans on the basis of outstanding teaching, and/or who had been appointed Distinguished Professors on the basis of their teaching. The faculty members who were invited to become protégés included not only assistant professors new to the professorate, but also those who had come to Purdue with some previous teaching experience.

The first official callout for the current FMN was October 4, 1999; it yielded 18 mentors. The program consisted of an introduction, presentations on mentoring, and an opportunity for junior faculty to meet with potential mentors in an informal setting. The protégés were provided with an "Intent to Participate Form," which listed particular areas of teaching they would like to improve such as large classroom lecturing, scholarship of teaching and learning, and so forth. After meeting with the potential mentors, protégés could indicate a particular mentor(s) with whom they would like to work, but the choice was not guaranteed. The FMN committee made the final decision on the mentoring pairs, in order to ensure that the interests of the protégé were matched with the expertise of the mentor. For example, it would not have been appropriate to match a mentor who was an accomplished large classroom lecturer with a protégé who wanted to be mentored on the scholarship of teaching. Once the pairs were selected, a letter was sent to each to each mentor and protégé encouraging them to establish monthly meetings. Nine mentoring pairs were established in the first year.

In April, 2000, which marked the end of the inaugural program, mentors and protégés were invited to a breakfast at which they would review whether the FMN had been worthwhile. Four mentors and seven protégés attended the session. At the breakfast, two staff members from 
Purdue's Center for Instructional Excellence (CIE) conducted a Small Group Instructional Diagnosis (SGID). One served as a facilitator for the mentors and the other for the protégés. The purpose was to determine what the protégés and mentors liked about the FMN, and also to elicit some suggestions for improvement.

Both mentors and protégés were extremely positive about the value of the program. The protégés generally liked: (a) having a reason to talk to others about teaching, (b) getting new ideas on teaching, (c) learning about teaching in different disciplines, (d) having a safe place to get input and ask questions, and (e) feeling as though they were "not alone." Suggested areas of improvement included: (a) holding informal meetings outside of work (they felt as though they were imposing on time of their mentors), (b) scheduling a fixed monthly meeting time, (c) making contact mutual (so that protégés felt comfortable contacting mentors for meetings, and so forth), (d) having more mentors at the callout to choose from, and (e) learning more about what might be expected from mentoring relationships.

The mentors generally liked: (a) the informal nature of the program, (b) the opportunity to help someone, (c) being paired with someone from another school, (d) the opportunity to reflect on their own teaching. Some areas for improvement that the mentors identified included: (a) beginning the program in August, rather than November, (b) share the experiences of each of the mentoring pairs with the entire group, (c) publicize the program more widely to involve more people, (d) convince deans and department heads that mentoring is important, (e) encourage the pairs to continue for a second year. The structure of the FMN program that was assessed as part of this study has remained largely unchanged.

Subjects

There were 43 faculty members in the 2001-2002 FMN program, including 25 protégés and 18 mentors. All 43 were asked to participate in the survey discussed below.

Procedures

In May 2002, all members were sent an email message requesting their participation in an evaluation of the FMN. They were directed to a questionnaire on the FMN website, which they were encouraged to complete. The members were told that the results of the survey would be shared with them at the fall meeting. An email reminder was sent the following month.

\section{Materials}

A questionnaire was adapted from Lacey's Mentoring Program Evaluation. ${ }^{14}$ The first three questions concerned the means by which and frequency with which pairs communicated. The fourth question asked respondents to rate the strength of the relationship. Question five asked respondents if they intended to work with their partner in the future, while the sixth asked if the program helped them become better teachers. The seventh question inquired whether the program had lived up to the respondent's expectations. The eighth question was open-ended and asked respondents to describe any unexpected benefits/outcomes of the program. The ninth question asked respondents whether they had attended any of the pre-arranged social gatherings 
for mentoring pairs. Question ten was open-ended and asked for recommendations to improve the program. Finally, respondents were asked to indicate their status as a mentor or protégé, (and number of protégés if mentor), age, sex, and academic rank.

\section{Data Analysis}

In qualitative inquiry, concepts should be the result of interaction between the data and the theoretical framework that guides the investigation. ${ }^{24,25}$ The responses to the open-ended questions were examined to identify summary themes that may or may not have been consistent with the mentoring literature.

Results

Twenty-four of the 43 FMN members responded to the online survey, for a response rate of $55.8 \%$. Due to the size of the sample, the study results may be indicative of Purdue's FMN program but cannot be generalized to other such programs either on or off campus.

The sample consisted of eight male mentors and one female mentor ranging in age from 41 to 67 years of age. There were 15 protégés of whom three were male, 11 female, and one respondent omitted "sex" from his/her survey. They range in age from 29 to 57, with three omitting their ages. To preserver anonymity, the results are presented so that no link can be made between mentors and protégés who worked with one another in 2001-2002.

Protégés were asked to report the number of times they contacted their mentor in a face-to-face meeting, by telephone, or e-mail. The results are shown in Table 1 below.

Table 1 Frequency of Contact between Protégé and Mentor via Face-to-face Meetings, Phone, or E-mail during 2001-2002 FMN Program.

\begin{tabular}{ccccc}
\hline Protégé & $\begin{array}{c}\text { Face-to-face } \\
\text { Meetings }\end{array}$ & $\begin{array}{c}\text { Contact via } \\
\text { Phone with } \\
\text { Mentor }\end{array}$ & $\begin{array}{c}\text { Contact via E- } \\
\text { mail with } \\
\text { Mentor }\end{array}$ & $\begin{array}{c}\text { Total \# Of } \\
\text { Contacts }\end{array}$ \\
\hline 1 & 4 & 0 & 20 & 24 \\
2 & 1 & 2 & 2 & 5 \\
3 & 0 & 0 & 5 & 5 \\
4 & 3 & 0 & 5 & 8 \\
5 & 8 & 0 & 15 & 23 \\
6 & 1 & 0 & 2 & 3 \\
7 & 2 & 3 & 5 & 10 \\
8 & 2 & 0 & 4 & 6 \\
9 & 6 & 0 & 11 & 17 \\
10 & 4 & 0 & 7 & 11 \\
11 & 6 & 2 & 20 & 28 \\
12 & 1 & 1 & 0 & 2 \\
13 & 6 & 2 & 30 & 38 \\
14 & 8 & 1 & 12 & 21 \\
15 & 1 & 1 & 1 & 3 \\
Mean & 3.5 & 0.8 & 7.9 & 13.6 \\
\hline
\end{tabular}


The total contact reported by protégés with mentors ranged from 3 to 38, with the mean number of total contacts being 13.6. The method used most by protégés to contact mentors was e-mail, with a mean of 7.9; the least preferred method of contact was by phone, with a mean of less than one phone call.

Protégés were asked if the FMN program lived up to their expectations and made them better teachers. They were also asked to rate the strength of the relationship they had with their mentors and whether they would continue working with their mentors beyond the 2001-2002 program, as shown in Table 2 below.

Table 2. Protégés' Perceptions of the FMN Program

\begin{tabular}{lllll}
\hline Protégé & $\begin{array}{l}\text { Lived up to } \\
\text { Expectations }\end{array}$ & $\begin{array}{l}\text { Made } \\
\text { Better } \\
\text { Teacher }\end{array}$ & $\begin{array}{l}\text { Strength of } \\
\text { Relationship* }\end{array}$ & $\begin{array}{l}\text { Continue } \\
\text { after 2002 }\end{array}$ \\
\hline 1 & Yes & Yes & 8 & Yes \\
2 & No & No & 1 & No \\
3 & No & No & 1 & No \\
4 & Yes & Yes & 8 & Yes \\
5 & Yes & Yes & 8 & No \\
6 & Yes & No & 6 & Yes \\
7 & Yes & Yes & 5 & Yes \\
8 & No & Yes & 5 & -- \\
9 & Yes & Yes & 10 & Yes \\
10 & Yes & Yes & 7 & Yes \\
11 & Yes & Yes & 8 & Yes \\
12 & Yes & Yes & 2 & Yes \\
13 & Yes & No & 7 & Yes \\
14 & Yes & Yes & 10 & Yes \\
15 & Yes & No & 5 & Yes \\
\hline
\end{tabular}

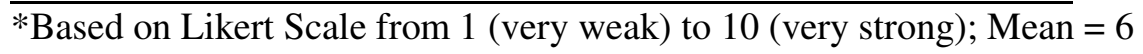

Twelve protégés indicated the program lived up to their expectations. The reasons given included remarks such as "It felt good to have advice and support," and "I liked the informal nature of the program...the match with the expertise provided the guidance I needed." Two of the protégés, whose expectations were not met, commented "We had lunch twice... there was not a lot of relationship development that occurred," and "I felt like my mentor did a lot more talking than listening and we never really established a plan." One even gave advice to future protégés, suggesting they "Make sure the mentor is willing to work."

Ten protégés indicated they felt they were better teachers after having been through the program. Comments included: "I started to focus on weak areas." "I learned to better teach large lectures after hearing some of my mentor's experiences." "I got constructive feedback to address the problems I was having." "I had discussions that helped me to have a better picture of what I was doing well, not doing well, and how to improve." It should be noted that of the five who indicated that their teaching did not improve, two had come to the program to focus on the 
research of teaching and one had not yet acted upon the advice of the mentor. The other two had not formed strong bonds with their mentors, as described above.

The strength of the relationship with the mentor ranged from one to 10 , with a mean of 6.1 . The nine protégés who rated the strength of the relationship above the mean made remarks such as: "My mentor was very friendly and helpful." "My mentor had good advice and helped put me at ease." "He was also very encouraging and really showed his caring about my progress." On the other hand, those who rated the strength of their relationship below the mean indicated it was due to infrequent contacts, and lack of rapport and/or commitment by their mentors. They made such comments as the mentor: "My mentor e-mailed me until I met him then I felt that he did not have much interest to meet me again." "He was not as responsive as I expected." "We had different personalities such that the I learned a great deal, but there was no rapport." One protégé took responsibility for the lack of progress in the mentoring relationship by stating that "My mentor was very helpful. I just haven't acted on the information yet."

The mentors' appraisals of the 2001-2002 FMN program are presented in Table 3.

Table 3. Individual Mentor Contacts with Protégé(s) and Program Evaluation

\begin{tabular}{ccccc}
\hline Mentor & $\begin{array}{c}\text { No. of } \\
\text { protégés }\end{array}$ & $\begin{array}{c}\text { Lived up to } \\
\text { expectations }\end{array}$ & $\begin{array}{c}\text { Made } \\
\text { Better } \\
\text { Teacher }\end{array}$ & $\begin{array}{c}\text { Continue } \\
\text { after 2002 }\end{array}$ \\
\hline 1 & 1 & Yes & Yes & Yes \\
2 & 1 & Yes & N/A $^{\text {a }}$ & Yes \\
3 & 2 & Yes & No & No \\
4 & 2 & Yes & No & Yes \\
5 & 1 & Yes & Yes & No \\
6 & 3 & Yes & Yes & No \\
7 & 2 & Yes & No & Yes \\
8 & 1 & Yes & Yes & Yes \\
9 & 2 & Yes & Yes & Yes \\
\hline
\end{tabular}

Notes; ${ }^{a}$ Retired

Most of the mentors had more than one protégé; one had three protégés. All nine of the mentors indicated that the FMN program lived up to their expectations. Some of their comments included "Mentoring is critical for junior faculty...the FMN is a good way to show junior faculty how to be a strong teacher without sacrificing research." "It gave us a linkage we wouldn't otherwise have had." "We work 65 hour weeks and it does take a special effort to get folks together. Still, I believe the FMN is a very effective mechanism for those who can take advantage of the opportunity."

Consistent with the findings of the Montclair State study cited above, ${ }^{7}$ over half of the mentors indicated that the program improved their teaching, as well as the teaching of their protégés. The reasons given included: "It made me rethink my own strategies in a large classroom setting. Ironically, I might have gotten more out of it than my partner." "It made me think about issues I should have but didn't think about." "As a mentor, I have found that conversations with 
(protégés) really help me think more carefully about my teaching and give me new ideas based on what "the protégé' is doing." "(Conversations with my protégé) remind me of items I need to update..."

All but three mentors planned to continue the relationship with their protégés after the program officially ended. One who responded "No" qualified that by saying, "Well, it could be yes depending on my partner." Another mentor who had three protégés had projects arranged with each of them, meaning that the relationship would continue beyond the 2001-2002 timeframe but end when the projects ended.

Finally, mentors and protégés were asked to provide suggestions for improving the FMN, indicated in Table 4 below.

Table 4 Protégé and Mentor Recommendations to Improve the Faculty Mentoring Network

\begin{tabular}{cccccc}
\hline & $\begin{array}{c}\text { Pair } \\
\text { Matching }\end{array}$ & $\begin{array}{c}\text { Mentoring } \\
\text { in Groups }\end{array}$ & $\begin{array}{c}\text { Mentoring } \\
\text { Education }\end{array}$ & $\begin{array}{c}\text { Program } \\
\text { Expansion }\end{array}$ & $\begin{array}{c}\text { No } \\
\text { Changes }\end{array}$ \\
\hline $\begin{array}{c}\text { Number of } \\
\text { Mentors }\end{array}$ & 1 & 1 & 1 & 2 & 2 \\
$\begin{array}{c}\text { Number of } \\
\text { Proteges }\end{array}$ & 1 & 3 & 4 & 2 & 2 \\
\hline
\end{tabular}

Five common themes emerged from the feedback: pair matching, mentoring groups, mentoring education, program expansion, and no changes. In terms of "pair matching," the mentor recommended "a more careful match between pairs that takes into consideration different schools and fields" while the protégé recommended that if "mentor had more than one protégé, they should come from different departments." With respect to "mentoring groups" the mentor and three protégés wanted to see groups meetings, seminars, and/or compare notes on mentoring experiences. One mentor suggested "lunch seminars where mentors could present 15-20 minute "pearls of wisdom" topics to both mentors and protégés" while the protégés suggested "more short social meetings, more evaluation of the progress of the protégés," and "more contact with program protégés to exchange experiences." One mentor and four protégés recommended "mentoring education." For example, one thought that "each mentoring pair should be required to formulate a letter of understanding as to what the purpose of the relationship would be ... so mentor and protégé get what they want out of the relationship." Protégés recommended, "workshops for mentors to teach them how to be good mentors," or "make sure the mentor is willing to work." The theme of "program expansion" referred to getting more faculty involvement both on mentor and protégé side of the equation. One mentor thought it would help to market the program to deans and department heads, while protégés wanted to see more "recruitment of mentors from all disciplines."

\section{Discussion}

This study sought to determine who is involved in the Purdue FMN program, the nature and strength of the relationship between mentoring pairs, whether or not those involved in the FMN program believed that their teaching was improved, and recommendations for improvement of the program. 
Consistent with recommendations in the literature cited above, participation in the FMN program was voluntary. Participants in program consisted of mentors who were more experienced faculty members and protégés who were new to the University faculty. Since the primary purpose of the FMN was to improve faculty teaching, such pairings supported the intent of the program.

The FMN committee recommended that pairs meet monthly to form a good relationship. Guidelines for creating formal mentoring programs stipulate some minimum frequency of interaction for mentors and protégés. 7, 14 Most participants were pleased with the program, stating that is lived up to their expectations. Clearly the most successful pairings were those that met frequently and found common ground on which to build a relationship. Conversely, those that failed to create such a relationship reported infrequent contacts and/or rapport. These findings indicate the need for the FMN program to provide additional support for the mentoring pairs, which is discussed in more detail below.

The success of the program was demonstrated by the 10 protégés whose teaching was improved. Of particular interest were the five mentors who also indicated that their teaching improved. This finding is consistent with the Montclair State Program cited above whose mentors also believed their teaching improved. ${ }^{7}$ It suggests that perhaps the program's explicit purpose could expand to incorporate the expectation that engaging in dialogue and discussing "best practice" on teaching can improve the teaching of both mentors and protégés.

Finally, participants were asked to suggest ways in which the FMN could be improved. Many were satisfied with the program and recommended it be expanded to include more faculty members. This indicated that the founding subcommittee had planned and developed an effective mentoring program at Purdue. However, many participants recommended that more thought be put into matching the mentor and protégé, and some time invested in educating them on how to have an effective mentoring relationship.

In order to strengthen the design and increase confidence that the positive results of a study do not largely reflect the views of the particular participants, Patton (1990) recommends utilizing multiple methodologies. That process is termed "triangulation." To triangulate the data, the authors utilized a second evaluation of the FMN conducted in February 2003 by its coordinator, ${ }^{26}$ which yielded highly similar results and increases confidence that our findings and the findings of the Small Group Instructional Diagnosis were not merely methodological artifacts. Questionnaires were sent to all 47 members of the 2003 FMN. Eleven mentors and 15 protégés responded. Using a 5 -point Likert scale $(5=$ strongly agree; $1=$ strongly disagree $)$ the study found the protégés agreed that their interactions in the network were beneficial $(\overline{\mathrm{X}}=4.36)$, that the time they invested in the program was worth it $(\bar{x}=4.36)$, and that they would recommend this program $(\bar{X}=4.29)$. The corresponding means for the mentors were $3,82,4.09$, and 4.55 .

Recommendations and Conclusions

Based upon the literature and the survey responses, this case study suggests that there are several 
courses of action that would make the FMN program, and others like it, more beneficial, particularly to the protégés:

1. Conduct an orientation session for mentors, giving clear guidelines of what is expected of them in terms of both quality and quantity of interaction. This would address the concern of several protégés that their mentors did not meet their responsibilities.

2. Broaden the criteria used to match mentor and protégé(s) to include such factors as personality, outside interests. This would address the lack of rapport that appears to have plagued a few of the mentoring pairs.

3. Encourage mentor and protégé(s) to enter into a contract of expectations, thus avoiding some potential misunderstanding about the nature and extent of the mentoring relationship.

4. Add group sessions to the program, encouraging exchanges among mentors and protégés to create a network. Ongoing support for the mentoring pairs is recommended as an essential strategy for program success. $3,4,5,7$

As evidenced by the Montclair State program, the likelihood of success can be enhanced by mandatory group meetings (Pierce, 1999). The Purdue FMN program would benefit from regular group meetings among mentors and protégés that would serve to encourage and support the relationships between and among mentoring pairs. With the support of the entire network, unsuccessful matches would not be as devastating, particularly to the protégés.

The benefits of mentoring are amply demonstrated by the literature cited in this case study of Purdue University's Faculty Mentoring Network. Data for the study indicate that the program has satisfied the needs of most of its participants. Combining the grooming mentoring and networking mentoring models should produce even better results as the FMN strives to assist new faculty to become better classroom teachers and researchers. With the criteria for promotion and tenure growing more stringent, mentoring can be key to faculty success.

\section{Bibliography}

1. Burlew, L. D. (1991). Multiple mentor model: A conceptual framework. Journal of Career Development, 17 (3), 231-221.

2. Haring, M. J. (1999). The case for a conceptual base for minority mentoring programs. Peabody Journal of Education, 74 (2), 5-14.

3. Swoboda, M. J., \& Millar, S. B. (1986). Networking-mentoring: Career strategy of women in academic administration. Journal of NAWAC, 8-13.

4. Haring, M. J. (1993). Mentoring for research: Examining alternative models. In N. Minghetti, et al. (Eds.). Research mentorship and training in communication sciences and disorders, proceedings of a national conference (pp. 117-125). Rockville, MD: American Speech Language-Hearing Foundation.

5. Kram, K. E. (1985). Mentoring at work. Glenview, IL: Scott, Foresman.

6. Cawyer, C. S., Simonds, C., \& Davis, S. (2002). Mentoring to facilitate socialization: The case of the new faculty member. International Journal of Qualitative Studies in Education, 15 (2), 225-242.

7. Pierce, G. (1998). Developing new university faculty through mentoring. Journal of Humanistic Education and Development, 37, 27-38.

8. Olsen, D. (1993). Work satisfaction and stress in the first and third year of academic appointment. Journal of Higher Education, 64, 453-471.

9. Bowen, H. B. (1986). American professors. New York: Oxford University Press.

10. Farylo, B., \& Paludi, M. A. (1985). Development discontinuities in mentor choice by male students. The Journal of Social Psychology, 125, 521-522. 
11. Perna, F. M., Lerner, B. M., \& Yura, M. T. (1995). Mentoring and career development among university faculty. Journal of Education, 177, 31-45.

12. Johnsrud, L. K. (1990). Mentoring for administrative staff: relationships that help and relationships that hinder. In K. M. Moore \& S. B. Twombley. (Eds.), Administrative Careers and the Marketplace. San Francisco: Jossey-Bass, Inc., 57-66.

13. Selby, J. W. (1998). Mentoring programs for new faculty: Unintended consequences? Teaching of Psychology, 26 (3). 210-211

14. Lacey, K. (1999). Making mentoring happen. Warriewood, NSW: Business and Professional Publishers Ltd.

15. Boice, R. (1992). The new faculty member. San Francisco: Jossey-Bass.

16. Meyers, H. W., \& Smith, S. (1999). Coming home - mentoring new teachers: A school-university partnership to support the development of teachers from diverse ethnic backgrounds. Peabody Journal of Education, 74 (2) 75-89.

17. Menges, R. J., \& Associates. (1999). Faculty in new jobs. San Francisco: Jossey-Bass.

18. Borisoff, D. (1998). Strategies for effective mentoring and for being effectively mentored: A focus on research institutions. Journal of the Association for Communication Administration, 27, 84-96.

19. Cawyer, C. S., \& Friedrich, G. W. (1998). Organizational socialization: Processes for new communication faculty. Communication Education, 47, 234-245.

20. Stake, R. S. (1994). Case studies. In N. K. Denzin \& Y. S. Lincoln (Eds.), Handbook of qualitative research (pp. 236-247). Thousand Oaks, CA: Sage.

21. Boyle. P., \& Boice, B. (1998). Systematic mentoring for new faculty teachers and graduate teaching assistants. Innovative Higher Education, 22 (3), 157-179.

22. Wenniger, M. D. (1997). New networking model of mentoring catches on at Purdue. Women in Higher Education, 6 (10). 1-2).

23. Schockett, M. R. \& Haring-Hidore, M. (1985). Factor analytic support for psychosocial and vocational mentoring functions, Psychological Reports, 57 (2), 627-630

24. Lindlof, T. R. (1995). Qualitative communication research methods. Thousand Oaks, CA: Sage.

25. Patton, M. Q. (1990). Qualitative evaluation and research methods (2nd ed.). Newbury Park, CA: Sage Publications.

26. Green, S. (2003). Report on the Evaluation of the Purdue University Faculty Mentoring Network. West Lafayette, IN: Purdue University, Office of the Provost.

\section{Biographical Information}

MARA H. WASBURN is an Assistant Professor of Organizational Leadership and Supervision (OLS) at Purdue University. She holds a Ph.D. from Purdue University. She teaches courses in women and technology, coaching and mentoring, and service learning. She is coordinator of the coop and internship programs in OLS, and serves as faculty advisor to Women in Technology. Her research interests focus on mentoring with an emphasis on women in technology-related disciplines

JOSEPH M. LA LOPA is an Associate Professor of Hospitality and Tourism Management at Purdue University. He holds a Ph.D. from Michigan State University. He teaches introduction to foodservice, lodging, and tourism; organizational management; and a sophomore honors course. His research focuses on tourism, hotel management; and operational analysis. 